\title{
Investment and employment from large-scale photovoltaics up to 2050
}

\author{
Wolf Grossmann • Karl W. Steininger • \\ Christoph Schmid • Iris Grossmann
}

Published online: 1 March 2012

(C) Springer Science+Business Media New York 2012

\begin{abstract}
Investments in renewable energy were at US\$211 billion in 2010 and developing economies overtook developed ones for the first time in terms of new financial investments in renewable energy. Photovoltaics for generation of electricity from sunlight has the highest growth rate among the competing forms of renewable energy and has now begun to achieve grid parity in some regions. If these trends of investments continue, solar energy will play a major economic role. We analyze these developments and assess the ensuing amounts of investment and employment for a range of sizes of the sector of solar energy. We find that by 2050 electricity from photovoltaics could cover up to $90 \%$ of total global energy demand, with a then global capital investment in our main scenario in photovoltaic manufacturing capacity at 500 billion US\$ $\$_{2010}$ by around 2030 and 1,500 billion by 2050 . Employment in photovoltaic manufacturing is predicted to rise to 6 million by 2050. Sensitivity analysis with respect to the core parameters of assumptions is supplied.
\end{abstract}

\footnotetext{
W. Grossmann · K. W. Steininger $(\varangle) \cdot$ C. Schmid

Wegener Center for Climate and Global Change, University of Graz,

Leechgasse 25, 8010 Graz, Austria

e-mail: karl.steininger@uni-graz.at

W. Grossmann

International Center for Climate and Society, University of Hawaii at Manoa, 1680 East-West Road, Honolulu, HI 96822, USA

K. W. Steininger

Department of Economics, University of Graz, Universitaetsstr. 15,

8010 Graz, Austria

I. Grossmann

Center for Climate and Energy Decision Making, Carnegie Mellon University,

5000 Forbes Ave, Pittsburgh, PA 15213, USA
} 
Keywords Renewable energy - Scenarios for solar energy ·

Investments in energy · Labor in renewable energy · Energy market development

JEL Classification Q41 $\cdot \mathrm{Q} 42 \cdot \mathrm{O} 13$

\section{Driving forces for a new energy system}

Today's economic system strongly depends on energy supply, which faces significant challenges. The dominating supply worldwide is still fossil fuel [85.1\% in 2008 (IPCC 2012)]. Large oil price fluctuations pose financial difficulties for the economy (Ayres 2008), as was evident with the sudden increases of crude oil price in 2008 and again in 2011. Future availability of oil is becoming highly uncertain, as is evident in the discussion of peak oil. Coal had been regarded as almost inexhaustible, although this view is disputed by Patzek and Croft (2010). Some view natural gas as a bridging energy to a sustainable energy future (MIT 2010). The word "bridging" indicates that fossil fuels will eventually be replaced by renewable energy.

On the demand side, governed also by energy efficiency and global economic growth, the recent high growth in China and India widens the range of reasonable demand scenarios. The first IPCC scenarios in 2000 (SRES) assumed economic growth between factors 4 and 32 by 2100 (Nakicenovic et al. 2001). Depending on growth, energy use and fossil fuel emissions in these scenarios increase by between factor 5 and 35. As the fossil fuel sector already has difficulties to meet current energy needs, increased difficulties can be expected with economic growth, even at low growth rates.

The only renewables with sufficient potential to meet a growing global energy demand are solar and to a lesser degree wind; the potential of each of all other forms of renewable energy is very limited (Lewis 2007a) —although they all will have to play their appropriate role. IPCC (2012) reports the range of estimates of global technical potential, with even the lowest estimate for direct solar at a multiple level of the highest available estimates of all other sources (wind and geothermal being the most relevant among them). Solar energy is used as heat for heating and processes, and as electricity through photovoltaics (PV) and solar thermal (ST), in particular as concentrated solar power (CSP). For overall demand, solar energy has a practical potential of about 600 terawatt (TW) (Lewis 2007b), based on World Energy Assessment 2000, within a range of 50-1,500 TW, depending on practical factors such as land fraction used. IPCC (2012) estimates a practical potential between $50-1,600 \mathrm{TW}$. This compares to a total global primary energy consumption of $16.5 \mathrm{TW}$ in 2009 . Of these, $6.5 \mathrm{TW}$ were used to generate $2.1 \mathrm{TW}$ of electricity at an efficiency of $31.3 \%$ (IEA 2009). Supplying just these $2.1 \mathrm{TW}$ of electricity from solar would decrease the primary energy demand by $6.5 \mathrm{TW}$.

In 2008 renewables accounted for $12.9 \%$ of the global energy supply, but direct solar for only $0.1 \%$ (IPCC 2012). The role of individual renewables will depend on their respective growth rates. Recent growth has been high (REN 21 2010): Wind turbines had the highest absolute growth with the addition of $38 \mathrm{GW}$ in 2009 and an 
average annual growth of $27 \%$ between 2004 and 2009, bringing the installed total to $159 \mathrm{GW}$. PV grew at $120 \%$ in 2010 with $19 \mathrm{GW}$ of new capacity to a total of 39 GW; annual growth during 2005-2010 was close to 50\% (REN 21 2011). Solar thermal (ST) grew by 264 MW to a level of 940 MW of capacity in 2009 with average growth of $12 \%$ between 2004 and 2009 and $41 \%$ in 2010.

In early 2010 more than 100 countries had enacted renewable energy policy targets and/or policies, up from 55 countries in early 2005 (REN 21 2010). Global renewable energy investments were at US\$211 billion, a 32\% increase over 2009, and a 540\% rise since 2004 (UNEP 2011). For the first time, developing economies overtook developed ones in terms of new investments in utility-scale renewable energy projects and provision of equity capital for renewable energy companies (UNEP 2011). US\$211 billion is a substantial amount. Zweibel et al. (2008) calculated that the US would have to invest more than $\$ 400$ billion to provide $69 \%$ of the US electricity supply and $35 \%$ of its total energy (including transportation) from solar power by 2050.

Increase of solar installations is triggered by a dramatic price decline. Costs of PV modules per MW have declined by 60\% in the period 2008-2011 (UNEP 2011). PV has reached grid parity (electricity production costs equal to those from fossil fuels) in parts of Italy in 2010 (Pew 2011), followed closely by parts of California, Hawaii and Spain (Zaman and Lockman 2011; Breyer et al. 2009). Consequently, PV achieved the highest growth of all renewables. As grid parity is achieved in further regions (Ahearn et al. 2011), this growth rate could remain very high for several years.

Based on falling costs for solar energy, large-scale schemes for solar electricity generation have been proposed. The Desertec organization plans to generate electricity for the EUMENA region (Europe, Middle East, North Africa) from wind and solar in the Sahara and Saudi deserts (Desertec Foundation 2010). Zweibel et al. (2008) proposed the ambitious US Solar Grand Plan which would replace $90 \%$ of its fossil fuels in 2100 .

As the global energy system is a major economic sector with a share of $8 \%$ in global GDP (IER 2010), the prospects for investment and employment in the PV sector become an issue of major interest. This paper presents an analysis of the scope for this development in quantitative terms. How fast can solar supply realistically be built up? What investment levels are necessary for a dominant share of global energy supply? Which size of labor force will be needed? At present, few people are trained in the field of PV and CSP, but demand for skilled workers will increase. An assessment of the volume of investment and employment in this growing sector needs learning curves on the development of PV, in particular with respect to levelized costs of energy (the gross energy cost as supplied to the system). The price leader for PV panels, First Solar, projects total systems manufacturing costs of \$1.40-1.60/Watt peak in 2015 and a gross margin of 15-20\%, corresponding to electricity costs of 7.25-8.8 $\phi / \mathrm{kWh}$ in the US Southwest (in the past, First Solar has consistently outperformed its projections, hence these numbers have credibility). As present solar electricity costs in the same region are at about $15 \phi / \mathrm{kWh}$, panel manufacturing costs and capital expenditures will have to decrease rapidly.

A global energy supply from PV and CSP for all energy needs, not just electricity, would need about $1.5 \%$ of the global desert area (Zweibel 2006; Lewis 
2007a). Using this comparatively small desert area to supply all energy is far less critical than using agricultural land for energy crops. PV has no moving parts, a life expectancy between 30 and 40 years (EC 2009), maintenance costs of less than $1 \not /$ $\mathrm{kWh}$ (Zweibel 2006), and it does not need water for operation-a big advantage in desert climates. The raw material for most PV panels (Wadia et al. 2009), silicon, is the second most abundant mineral in the upper earth crust.

The main obstacle to large-scale use of PV, CSP and wind are their intermittency due to the cycles of day and night, and attenuation from cloudiness or ice on panels. Combining PV, CSP and wind decreases intermittency to some extent (Palmintier et al. 2008). Significant reductions in intermittency can be achieved through the combination of solar installations in different time zones and in the two hemispheres, based on optimal site selection and optimized generation and storage capacity (Grossmann et al. 2011). Global or almost global solar systems could completely eliminate intermittency even without energy storage (Grossmann et al. 2011). The configuration with the minimum number of sites includes cells of $1^{\circ} \times 1^{\circ}$ each (about $111 \mathrm{~km} \times 90 \mathrm{~km}$ at latitude $35^{\circ}$ ) in the east and west of Australia, the Saudi Desert, the westernmost Sahara, the Atacama and Mojave Deserts, i.e. just six sites. This configuration could constantly meet a demand of $>2$ TW.

With such prospects, significant growth rates are predicted. Bloomberg (2010) foresees 42\%/y growth for PV in the US during 2010-2020, whereas First Solar foresees compound annual revenue growth rates of 5-10\% after 2011, or, with the projected decrease of manufacturing costs and margins an annual increase of manufacturing by 14-20\%. This shows the large uncertainty regarding the volume of manufacturing and costs. Accordingly, we provide a range of plausible outcomes. We begin with an analysis of possible growth rates in Sect. 2. In Sect. 3 we develop a collection of learning curves for the PV sector. Learning curves give manufacturing costs, which are used to derive estimates of employment and investment on a global basis in Sect. 4. The final section provides conclusions and recommendations.

\section{Possible growth rates for solar energy}

Due to the favorable development of costs and the increasing pressure to substitute fossil fuels by renewable energy, it seems highly likely that some of these grand schemes will be implemented. The eventual size of the solar sector depends on several factors, in particular, the fraction of the total energy demand that has to be met by renewable energy, the growth of energy demand, and the competitive situation of solar. The goal of the European Union, for example, for renewable energy is an almost total decarbonization of energy supply by 2050 (EU 2011b).

\subsection{The share of solar in future energy supply}

To investigate how high the share of solar energy could become, Table 1 shows the average use of primary energy for OECD countries. Globally, electricity generation 
Table 1 Primary energy demand by sector in per cent, OECD average (IEA 2010; EIA 2011; EU 2011b)

\begin{tabular}{ll}
\hline Sector & Demand (\%) \\
\hline Transportation & 25 \\
Buildings & 30 \\
Households & 15 \\
Services, service sector & 15 \\
Goods production & 15 \\
\hline
\end{tabular}

consumes $39 \%$ of the primary energy (as was said before, 6.5 TW of 16.5 total). These $39 \%$ could be replaced by solar energy. Electricity is the main form of energy consumed by the sectors household/living and services as well as about half of the energy consumed in production. Electric vehicles (EVs) use electricity instead of fuels. Road transportation consumes about $80 \%$ of the energy used in the transportation sector. Thus, to the degree that EVs develop well they would allow to shift up to $80 \%$ of the $25 \%$, i.e. up to $20 \%$ of primary energy consumed by the transportation sector to renewables.

Architecture has manifold options to decrease energy consumption by buildings; some of which go far beyond simple thermal insulation, as in the case of the highly sophisticated architecture of the Pearl River Tower in Guangzhou/China (EU 2011a). The European Parliament has mandated that all new buildings in Europe have to be "nearly zero-energy" beginning 2021 (EU 2010, EC 2011). There are reports of problems with some types of such buildings, e.g. mildew on walls, insufficient air ventilation with resulting indoor pollution etc. Either those problems will be overcome and zero-energy buildings succeed, which would decrease primary energy consumption in the very long run by another $30 \%$, or-that is the other extreme-such buildings fail so that renewable energy would have to provide another $30 \%$ of present energy consumption. We include the range between these extremes into our projections.

In total, $39 \%+20 \%=59 \%$ of primary energy could be replaced in the electricity sector and the transportation sector, respectively, and up to $30 \%$ in buildings, in total-assuming that the global and OECD numbers converge in the long run-a figure up to almost $90 \%$ of all primary energy.

The remaining $10 \%$ cannot be substituted by electricity, as it is fuels in the transportation sector for aviation, shipping, pipelines and non-electric trains and non-energy use in production, e.g. use of coal as a chemical agent in the production of pig iron or crude oil used by the chemical industry as a basis for production of manifold chemicals.

As $6.5 \mathrm{TW}$ of primary energy give $2.1 \mathrm{TW}$ of electricity, the efficiency here is roughly $32 \%$.

The efficiency of EVs is about $90 \%$ whereas vehicles with internal combustion engine have an efficiency of about $30 \%$. As road transportation consumes $20 \%$ of the primary energy demand of $16.5 \mathrm{TW}$, i.e. 3.3 , EVs would decrease this demand to $1 / 3$ or $1.1 \mathrm{TW}$.

The total electricity demand, current electricity plus using EVs, at the current demand level for electricity and transport services thus would amount to 3.2 TW. 


\subsection{Energy demand scenarios}

Taking into account increased efficiencies from use of electricity, Fthenakis et al. (2009) argue that the energy demand in the US will be about the same in 2050 as it was in 2009, taking into account economic growth. This argument does not fully carry over to the global situation as economic growth in developing countries might be higher than in developed countries. Using a global economic growth of $3.3 \%$ per year as was the long-term average (Maddison 2001), and an increase of energy efficiency by $1 \%$ per year, which was also a long-term average, energy demand would increase by $3.3 \%-1 \%=2.3 \%$ per year, which from 2009 to 2050 gives a factor of 2.5. The demand for electricity as derived above at $3.2 \mathrm{TW}$ multiplied by factor 2.5 gives a demand in 2050 at 8 TW. For total electricity demand in 2050 we have to add demand from switching the energy supply for buildings. Applying the factor of 2.5 to the current primary energy demand for buildings (5 TW), and adjusting for a share of one-third of buildings having turned to nearly zero-energy buildings by 2050 , gives another 8.3 TW electricity demand. In total we get roughly 16.5 TW of electricity demand in 2050.

Alternatively, the IPCC-SRES from 2001 projected an increase in energy consumption between a factor of 5 (1.6\%/a) and 35 (3.6\%/a) until 2100, which corresponds to a factor of 2-14 increase for renewable electricity if higher efficiencies of electricity are taken into account. The electricity demand in 2050 would be between 8.25 and 18 TW for the lower bound and up to 26 TW if buildings are to be included. Electricity demand in 2050-according to these scenarios-could thus be between 8 and 26 TW.

\subsection{Solar generation capacity}

The solar generation capacity which is necessary to fulfill this demand depends on the locations of the solar installations. If the solar insolation in a location is $w \mathrm{kWh} /$ $\mathrm{m}^{2} /$ year, then the necessary solar capacity to give $1 \mathrm{~kW}$ is $8,760 / w$ in $\mathrm{kW}$ peak $(8,760$ is the number of hours in 1 year; typical values of $w$ are between $970 \mathrm{kWh} /$ $\mathrm{m}^{2} /$ year in the northern parts of Europe, $1,150 \mathrm{kWh} / \mathrm{m}^{2} /$ year in wine-growing regions in Europe, $1,700 \mathrm{kWh} / \mathrm{m}^{2} /$ year in one of the sunniest locations in Europe (Guadix in Spain which is the location of three CSP power stations with $50 \mathrm{MW}$ each), and $\sim 2,300 \mathrm{kWh} / \mathrm{m}^{2} /$ year in desert regions around the world at $35^{\circ}$ latitude. $\mathrm{kWp}$ is a standardized unit to specify the output of a solar panel.). Hence, for an output of $1 \mathrm{~kW}$ the necessary capacity is $\sim 9 \mathrm{kWp}$ in northern Europe, $\sim 7.5 \mathrm{kWp}$ in wine-growing regions in Europe, $5 \mathrm{kWp}$ in Guadix and $3.8 \mathrm{kWp}$ in typical desert regions (Table 2).

Naturally, the fraction of energy that will be met with solar depends on many factors, including social and political. We will here neglect social and political factors; Grossmann et al. (2011) show that it is much cheaper to generate electricity in the Sahara and transmit it to Europe than generating the electricity in Europe, even taking into account transmission costs. As was said above, PV has by now achieved grid parity in some regions, so that the further development of costs of PV is crucial for the penetration rate it may achieve. However, the European population, 
Table 2 Examples of locations and loads and the necessary solar generation capacity in kWp (third column) and TWp (fourth to sixth column) to meet this load

\begin{tabular}{lllllc}
\hline Location & $\begin{array}{l}\text { Insolation } \\
\left(\mathrm{kWh} / \mathrm{m}^{2} / \mathrm{y}\right)\end{array}$ & $\begin{array}{l}\text { Generat. cap } \\
\text { for } 1 \mathrm{~kW}\end{array}$ & $\begin{array}{l}\text { Capac for } \\
8.25 \mathrm{TW}\end{array}$ & $\begin{array}{l}\text { Capac for } \\
18 \mathrm{TW}\end{array}$ & $\begin{array}{l}\text { Capac for } \\
26 \mathrm{TW}\end{array}$ \\
\hline Graz/Austria & 1,500 & 5.8 & 48 & 104 & 151 \\
Hamburg/Germany & 1,360 & 6.4 & 53 & 115 & 166 \\
Sahara desert & 2,300 & 3.8 & 31 & 68 & 99 \\
Mojave desert & 2,300 & 3.8 & 31 & 68 & 99 \\
Atacama desert & 2,750 & 3.2 & 26 & 58 & 83 \\
\hline
\end{tabular}

like populations elsewhere, may prefer domestic supply. The respective costs of solar compared to other forms of energy supply is a most important indicator but does not suffice to predict the eventual penetration rate.

Very different growth rates are possible for solar. Global manufacturing capacity for PV grew by $140 \%$ in 2010 (Metha 2011) to 19 GWp. Still, this manufacturing capacity is so low that it would need 3,300 years to fulfill the current global energy demand of 12 TW (16.5 TW minus current primary energy demand for thermal electricity production, i.e. $6.5 \mathrm{TW}$, plus thermal electricity output at $2.1 \mathrm{TW}$ ). However, if manufacturing capacity continues to grow at the present rate, it would take $~ 8.2$ years to manufacture the capacity to meet a demand of $12 \mathrm{TW}$. Meeting a load of 12 TW needs very different installed capacities depending on the positioning of the generating capacity, as was outlined above. These are ranging from $50 \mathrm{TWp}$ in an optimized global network that uses only desert areas on both hemispheres, to $120 \mathrm{TWp}$ if the US Southwest were to produce all of this electricity, and up to $>200 \mathrm{TWp}$ if only the territory of the European Union would be used (based on Grossmann et al. 2011).

The general judgment is that present growth rates of PV manufacturing will considerably decline. We use two statements, one from Bloomberg, one from First Solar (FS), on predicted or planned growth rates and extend these to 2050 for a long-term projection of the possible size of the solar sector. The resulting considerable variations of expected growth rates allow a sensitivity analysis on employment and investment.

FS has announced to grow by $240 \%$ between the 2 years 2011 to the end of 2012 , but may have revised these plans due to global overcapacity. Bloomberg (2010) projected constant annual growth rates of $42 \%$ for the US solar market between 2011 and 2020. We develop one scenario for global installed capacity up to 2050 as given in Table 3 that is based on the $16.5 \mathrm{TW}$ of electricity demand in 2050 as derived in the previous section as main scenario (and representing also a medium value of electricity demand in 2050 for the IPCC SRES scenarios as given above in the range of $8-26 \mathrm{TW})$. The scenario for PV growth in Table 3 allows $90 \%$ renewable (here PV) supply of energy demand in 2050. The remaining $10 \%$ of energy demand need other forms of energy, in particular fuel for airplanes and ships and coke for production of pig iron. The installed capacity of $66 \mathrm{TWp}$ translates to a supply of $16.5 \mathrm{TW}$ when, for example, $90 \%$ of the capacity are located under solar 
Table 3 Scenario for development of PV installed capacity that could meet $90 \%$ of the energy demand in 2050

\begin{tabular}{llllc}
\hline Year & $\begin{array}{l}\text { Growth } \\
(\% / y e a r)\end{array}$ & $\begin{array}{l}\text { Installed capacity, } \\
\text { global } C(t)(\mathrm{TWp})\end{array}$ & $\begin{array}{l}\text { Number } \\
\text { doublings }\end{array}$ & $\begin{array}{l}\text { Manuf. } \\
\text { capacity, } \\
\text { global (GWp) }\end{array}$ \\
\hline 2010 & 120 & 0.03 & 0.0 & 19 \\
2015 & 33 & 0.3 & 5.0 & 157 \\
2020 & 21 & 2 & 7.7 & 681 \\
2025 & 17 & 7 & 9.5 & 1,754 \\
2030 & 11 & 17 & 10.7 & 3,508 \\
2035 & 7 & 30 & 11.6 & 5,517 \\
2040 & 5 & 45 & 12.1 & 7,491 \\
2045 & 3 & 56 & 12.5 & 9,009 \\
2050 & 2 & 66 & 12.7 & 10,120 \\
\hline
\end{tabular}

insolation of $2,300 \mathrm{kWh} / \mathrm{m}^{2} /$ year (desert areas) and $10 \%$ are of building integrated type at $1,300 \mathrm{kWh} / \mathrm{m}^{2} /$ year (a middle to southern European location).

The growth rates underlying Table 3 are far below the numbers given by Bloomberg (2010). There is nothing exceptional in these growth rates given the past experience with PV as one of the fastest growing technologies in human history. China seems poised to master the political will to secure its energy supply through renewables, see e.g. the massive Chinese investment in renewable energy technology with $80 \%$ of the global manufacturing of PV cells. Thus, a considerable fraction of the $66 \mathrm{TWp}$ could be constructed in the Asian/Australian region along the lines of the Desertec Asia outline.

The rapid decrease in panel prices encourages a growing number of businesses, utilities and other organizations to invest in PV installations. For example in the US, non-residential solar projects rose by $41 \%$ within 2 months to $24 \mathrm{GW}$ (Korosec 2011).

Although the need for implementing a new energy system seems to be pressing, and although the technologies are improving fast and are achieving grid parity in ever more countries, the growth rates could be very different, higher or lower, from those specified in Table 3. For our estimate of employment and investment we will use the growth rates in Table 3 as the maximum and calculate a range for employments and investments also using markedly lower growth rates.

The development of installed capacity $C(t)$ is limited by the maximum capacity $K$ for renewable energy. This situation is typically described by the logistic differential equation $d C / d t=a C(1-C / K)$ with the constant growth rate $a$ and the maximum $K$ of $C$; for $C=K$, growth becomes 0 . The solution of this differential equation is tedious but can be well approximated by an equation of the form $C(t)=u_{0}+v t^{n} /\left(w^{n}+t^{n}\right)$ with the initial value at time $t=0$ for capacity of $u_{0}$ (i.e. $19 \mathrm{GW}$ in 2010). The maximum value of $C$ for $t \rightarrow \infty$ is given by $v$. At time $t=w$ this expression has the value $u_{0}+v / 2$. The function given in Eq. 1 approximates a solution of the logistic differential equation with initially high growth and later market saturation: 


$$
C(t)=19+28000 \cdot(t-2010)^{2.4} /\left(45^{2.4}+(t-2010)^{2.4}\right), C(t) \text { in GWp }
$$

This function approximates the capacity numbers given above in Table 3 for the period 2010-2050 by choosing $v, n$ and $w$. In the years from 2011 to 2020 it gives much lower capacities than those in Table 3, but after year 2020 its error is $<7 \%$, after 2027 the error is $<2 \%$, when the development of employment and investment is most pronounced.

\section{Learning curves for PV}

We need costs for assessing the investment necessary for meeting the electricity demand in 2050 by PV. The investment also allows an estimate how employment in this sector may evolve. Development of costs is typically anticipated with learning curves, which in the case of PV have been quite reliable.

A typical learning curve for a new technology has a negative exponential shape. This is because the progress of a new technology is often very fast initially but slows down over time as the technology is approaching its maximum potential. If learning curves have a footing they can show the minimal cost level due to resources and the minimum amount of labor.

The present rapid decrease of costs for PV was brought about by the advent of competitive second generation PV panels. Precursors of first generation PV panels have been made practical for satellites in the early 1960s, and costs were of minor importance for that application. First generation PV panels use comparatively thick layers of silicon. Second generation PV panels use thin-film technology for the photosensitive layer, e.g. the CdTe-panels by Fist Solar (FS). Whereas first generation PV is an established technology with slow learning rates, thin-film is a young technology and its learning curve is still rapidly sloping downward. Second generation CdTe-panels became cheaper than first generation Si-panels at around 2004 and are now cheaper by more than $30 \%$. As the market potential is so big, the manufacturers that use silicon-technology have sharply increased their R\&D to stay competitive and could again speed up their learning curves. Accordingly, the PV industry is developing fast with a high intensity of R\&D and continuing significant investments also in the exploration of thin-film materials and even "third generation" technologies, e.g. very low cost low to medium efficiency organic modules (Wang et al. 2010) or dye-sensitized cells (Goldstein et al. 2010), very high efficiency quantum cell and nanotechnology modules (Unold and Schock 2011; Kamat and Schatz 2009) and solar concentrator systems (Raugei and Frankl 2009).

\subsection{Learning curves for electricity costs from PV}

Electricity costs from PV depend on the costs of the PV panel and costs of installation, connection to the grid and other systems related factors. These latter factors together constitute the balance of system (BOS). The total systems costs are the sum of the panel manufacturing costs times the margin of the manufacturer for the panel, plus the costs for the BOS times the margin for the BOS. 
Costs of both, PV panels and BOS, are usually given as \$/Watt peak. Panel costs of $1 \$ / \mathrm{Wp}$ correspond to levelized electricity costs (LCOE, i.e. the costs including amortization and interest rate) of $4.4 \mathrm{c} / \mathrm{kWh}$ at a yearly insolation of $2,300 \mathrm{kWh} / \mathrm{m}^{2}$ (Zweibel 2006), an insolation level which is typical for areas in or adjacent to the Mojave Desert in the US or for Phoenix, Arizona or for large parts of the Sahara and Australian deserts. Levelized costs include amortization and interest rate but not operation and maintenance. Here, the $4.4 \phi / \mathrm{kWh}$ correspond to an interest rate of $7 \%$, and 30 years lifetime of the equipment.

The development of the LCOE of PV panels depends on many issues, as we discuss below. Hence it is amazing that a simple learning curve $c_{1}(t)$ describes quite well the decrease of costs by $20 \%$ per doubling in the volume of manufacturing (Trancik and Zweibel 2006):

$$
c_{1}(t)=c_{0} 0.8^{\left(\ln \left(C(t) / C_{0}\right) / \ln (2)\right)}
$$

where $c_{0}=1.23$ is the cost in $\$ / \mathrm{Wp}$ in year 2007 (the first year for which the number of doublings is available), $C(t)$ (in $\mathrm{GW}$ ) is the capacity in year $t$ and $C_{0}=0.1$ is the capacity in year 2006 .

$c_{1}(t)$ in Eq. 2 would ultimately decrease to 0 with increasing number of doublings $n$. This is not possible due to the costs of resources used for manufacturing and the minimum required amount of labor for production. Hence, Eq. 2 is restated with a footing $F$ such that the footing plus the value of the other terms of the equation approximate minimum costs of panel over time. The parameters of the learning curve are determined using minimization of the square of the difference between the learning curve and the time series of historic panel costs plus the value for costs from the roadmap of FS for 2015. With the number of doublings in manufacturing capacity given by $n(t)=\ln \left(C(t) / C_{0}\right) / \ln (2)$ this gives the learning curve:

$$
c_{2}(t)=0.3+1.2 \cdot 0.78^{n}
$$

The footing value 0.3 is still higher than the expected minimal costs. This learning curve is fine for a lower number of doublings in manufacturing, but for the longer term a cost function with a lower footing is necessary. This is calculated through minimization using the additional cost factor $\$ 0.2 / \mathrm{Wp}$ in 2035 . For this case, Eq. 3 becomes

$$
\tilde{c}_{2}(t)=0.05+1.58 \cdot 0.811^{n}
$$

Manufacturing costs following these learning curves are given in Fig. 1. Both learning curves descend too fast until 2010; afterwards learning curve $c_{2}$ is above the projected decrease, whereas $\tilde{c}_{2}$ is below. The best approximation to the historic data is given by a learning curve that decreases costs per year by $12.9 \%$, which was the average historic decrease achieved by FS (not shown), independent from the number of doublings, with costs in year $n, c(n)=1.59 \cdot(n-2004)$ and initial costs of $\$ 1.59 / \mathrm{Wp}$ in year 2005. This learning curve also has 0 as its lower limit value. This simple curve is most appropriate for the first 5 years and has then to be replaced by a curve with footing. These differences have little influence on the long-term pattern of investment and employment, as large-scale use of solar energy depends on the achievement of grid parity, which is achieved by all learning curves by 2015 . 


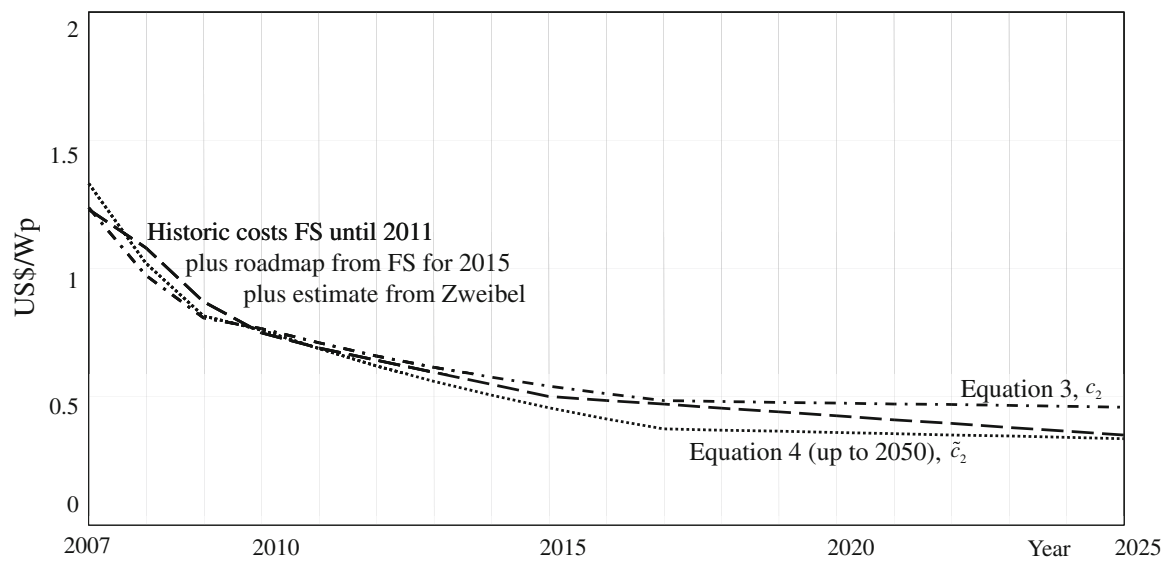

Fig. 1 Manufacturing costs of PV panels with different footing and different learning from doubling

The profit rate of PV panels shows an interesting pattern of exactly the type that has to be expected from economic theory. Several countries gave extremely high subsidies for electricity from solar in the form of feed-in tariffs, e.g. Germany and Spain. Demand grew, accordingly, much faster than supply, so that companies with the lowest manufacturing costs had for years shares of profits in revenues above $50 \%$ (FS 2010b). High subsidies were initially in accordance with very high costs of panels and BOS from companies that would not have been profitable without subsidies. High subsidies caused a boom in rooftop PV, so that country after country decreased its subsidies markedly. Several companies have now gone bankrupt, e.g. Solar Millenium (a manufacturer of CSP), others are on the "death list" of several analysts (e.g. Q-Cells), and the stock market value of the price leader, FS, decreased by $80 \%$ within several weeks. As subsidies will be further decreased, the expectation is that after $2015 \mathrm{PV}$ has to be able to survive in the markets on its own. The profit rate will decrease substantially; in its 2012 guidance (Ahearn et al. 2011) FS states that it will decrease its gross margin to $15-20 \%$.

In 2005 the costs for BOS per Wp were about the same as the costs for a PV panel, but decreased slower afterwards. In summer 2010, the costs for a panel from FS were $\$ 0.75 / \mathrm{Wp}$; the costs of BOS were at $\$ 1.29 / \mathrm{Wp}$. In 2011, FS could lower the costs for a panel in its most effective plant to $\$ 0.69 / \mathrm{Wp}$, the costs of BOS to $\$ 0.98 /$ $\mathrm{Wp}$, a decrease by $24 \%$. The roadmap for costs of BOS in the 2012 guidance (Ahearn et al. 2011) shows costs of $\$ 0.9 / \mathrm{Wp}$ already in 2012 , which is below the previous goal of FS of \$0.91-0.98/Wp in 2014, and \$0.70-0.75/Wp in 2014.

Thus in 2011 total systems costs were at $\$ 1.67 / \mathrm{Wp}$, which according to Zweibel (2006) gives LCOE of $\sim 7.7 \phi / \mathrm{kWh}$ from manufacturing costs in regions with an annual insolation of $2,300 \mathrm{kWh} / \mathrm{m}^{2}$. A share of profit in revenues of $50 \%$ increases this number to $\sim 15 \phi / \mathrm{kWh}$; a $30 \%$ share would increase it to $11 \phi / \mathrm{kWh}$. $15 \phi / \mathrm{kWh}$ is still more expensive than electricity from coal which can be as low as $\sim 4 \phi / \mathrm{kWh}$ for baseload plants (PB Power and Royal Academy of Engineering 2004). In 2015 total system costs would decrease to $\$ 1.20-1.29 / \mathrm{Wp}$, and the price with a share of 
profit of $15 \%$ to $\$ 1.41-1.52 / \mathrm{Wp}$ corresponding to electricity costs of $6.20-6.78 \propto$ / $\mathrm{kWh}$. Additionally, there will be development costs incurred by the system owner, which according to FS are typically around $\$ 0.20 / \mathrm{Wp}$. This would add $0.9 \phi / \mathrm{kWh}$. Even very cautious projections for the price of electricity from coal anticipate an increase such that at $\sim 7 \phi / \mathrm{kWh}$ grid parity of PV will have been achieved also in those regions which have very low costs of electricity (Grossmann et al. 2010).

As all aggregated learning curves are limited in their performance, we analyze individual cost factors in more detail. Of major importance is the efficiency of panels, as a panel with higher efficiency gives more output from the same BOS than a panel with a lower efficiency. Other than that there is no direct relationship between efficiency and costs of the panel per Wp. Increasing the efficiency of a panel can increase manufacturing costs so much that the LCOE from a more efficient panel is higher. First Solar is constantly increasing the efficiency of its panels from an initial value of $7.5 \%$ in year 2002 to $11.7 \%$ (2011, Q2). The present efficiency of the panels of FS at $11.7 \%$ is still comparatively low, as some Si-panels have efficiencies at around $20 \%$. Although Si-panels are more expensive per Wp (by about $50 \%$, i.e. $\$ 0.76 / \mathrm{Wp}$ compared to about $\$ 1.10-1.30 / \mathrm{Wp}$ ) the BOS-costs for these more expensive panels are lower. FS calculates that a $2 \%$ increase in efficiency lowers BOS-costs by $\$ 0.1 / \mathrm{Wp}$ (Ahearn et al. 2011). FS has recently developed PV panels of its CdTe-type which have a much higher efficiency of $17.3 \%$. Moreover, FS could produce panels on its present manufacturing equipment which have an efficiency of $13.4 \%$. FS expects to achieve $14.5-15 \%$ in 2015.

Additional cost factors in electricity supply from PV can be the transmission lines between solar locations in desert areas and the areas of consumption. Average costs for transmission from the US southwest to consumers are about $2 \phi / \mathrm{kWh}$ (Fthenakis et al. 2009); the same cost is given by Desertec (2010) and DLR (2006) for transmission from the Sahara and Saudi Desert to Europe, so that investments for transmission lines could be in the range of $2 \phi / \mathrm{kWh}$ or about $1 / 3$ of the total system costs of PV. Additionally, storage is necessary in most configurations to overcome intermittency. Costs of long-term storage can add 3-4 $\phi / \mathrm{kWh}$ (Fthenakis et al. 2009); storage for up to $24 \mathrm{~h}$ can be thermal storage with costs of $\sim 1 \phi / \mathrm{kWh}$; but thermal storage needs CSP (Biello 2009), which is now about $25 \%$ more expensive than PV (Mahon 2011). Both, storage and transmission lines further increase employment and investment in the sector of renewable energy. Values for amount of storage, costs of transmission lines, costs of electricity generation and necessary capacity are given for 12 regional, supra-regional and global configurations in Grossmann et al. (2011).

\subsection{Analyzing the elements in aggregated learning curves for panel production and BOS from economies of scale}

There are four causalities triggering economies of scale: line run-rate, decrease in material costs, decrease in costs of labor, and decrease in system costs. We will briefly review each of these factors.

Manufacturing at FS is organized in lines; the manufacturing of one panel is a continuous, highly automated process of about $2.5 \mathrm{~h}$. The line run rate gives the 
yearly amount of panels in megawatt (MW) produced by one line. The higher the annual output per line the lower the manufacturing costs. In the past 4 years FS has increased its line run rate by about $12 \%$ /year to $59.6 \mathrm{MW}$ at the end of 2010 (Cheyney 2010). The company's roadmap calls for hitting the $80 \mathrm{MW}$ run-rate mark in 2014 , an increase by $34 \%$ in 3-4 years or about $10 \%$ /year. Faster run rates increase labor productivity but do not decrease costs of materials.

Regarding decrease in material costs, Buller (2008) stated "Materials cost is $\sim 50 \%$ of typical TF (thin film)-module cost. Current materials are still nonstandard" and "Volume drives the custom materials towards raw material cost". $50 \%$ of module manufacturing costs of $\$ 1.08 / \mathrm{Wp}$ (in 2008) would mean $\$ 0.54 / \mathrm{Wp}$ for material costs. Green (2010) calculated material costs of $\$ 0.53-\$ 0.66 / \mathrm{Wp}$ for FS in Q4/2009. Past decrease of material costs, according to Green (2010), was due to improved production yield (less waste), and thinner layers of photosensitive material. Panel development will continuously lower the specific material demand per $\mathrm{Wp}$, use cheaper materials and through increasing volume will decrease the price per unit of material.

The decrease in the costs of labor has two main components, faster line run-rates so that the same amount of labor gives higher output, and increase in labor productivity due to higher automation. FS does not expect significantly lower costs for labor from manufacturing in countries with low wages due to the high degree of automation. In 2010, FS had 3,690 employees per $1 \mathrm{GW}$ of production capacity. Many of these are not active in production, but work in acquisition, management or research and development.

Zweibel (2005) assumes lowest possible costs of BOS of $\$ 0.20 / \mathrm{Wp}$. This number is reasonable for utility scale installations where most of the labor could be done by robots, and where inverters are no longer needed if the direct current (DC) from the panels is fed into DC transmission lines. None of the materials for BOS is scarce or special; thus material costs can become low.

Singling out the footing $(\$ 0.2 / \mathrm{Wp})$ from the early 2010 BOS costs of $\$ 1.29 / \mathrm{Wp}$, and using the observed BOS cost decrease from FS at $16 \%$ per year we get for the costs of BOS over time $c_{B}(t)$ :

$$
c_{B}(t)=0.20+1.09 \exp ((t-2009) \ln (0.8))
$$

Equation 5 takes the value of $\$ 1.29$ for 2009 , $\$ 0.76$ for 2012, $\$ 0.56$ for 2014 , $\$ 0.21$ for 2030 and after 2054 it stagnates at $\$ 0.20$. The year 2014 is seen by many analysts as the break-through year for PV; but for 2014 BOS costs from Eq. 5 are still at $\$ 0.56 / \mathrm{Wp}$, which is $\$ 0.7 / \mathrm{Wp}$ with $20 \%$ margin, i.e. the same number as in the 2012 roadmap from FS for 2014.

\subsection{Reduction of profit margin}

Reduction of profit margin is not a learning curve, but the profit margin has to be taken into account to get prices. The cautious assumption here is that the profit margin is already somewhat below the value reported for the past by FS (FS 2010 b) — we start with a profit margin of $50 \%$ (corresponding to share of profits in revenues of $33 \%$ ) - and assume that it will linearly decrease to $30 \%$ until 2020 due 
to increased competition and stay at that level for the remaining period (Ahearn et al. (2011) foresee an even stronger decline of the margin to 15-20\%).

$$
c_{4}(t)=1.5((2020-t)+(1.3 / 1.5)(t-2010)) / 10
$$

In 2010, $c_{4}$ has a value of 1.5 , which declines to $c_{4}=1.30$ by 2020 . Equation 6 specifies the factors with which the manufacturing costs of panels have to be multiplied to get the sales prices over time. This assumed decrease in profit margin leads to a price reduction of $13.3 \%$ relative to the initial sales price of PV panels.

\subsection{Overall 'learning' curve for price development}

The learning curve from increased production [Eq. 2 and the variants (3) and (4)] and the development of profit rates (Eq. 6), operate independently from each other. One depends on the growth of production volume of PV panels, the other on the increase of competition through diffusion of innovation. The sales price of PV panels, Eq. 7, is the product of the manufacturing costs from Eq. 2 with the margin from Eq. 6:

$$
c(t)=c_{1}(t) c_{4}(t)
$$

The equivalent equations are needed for the costs of BOS and the ultimately resulting total costs of electricity. The equations are almost identical to the equations for panels, but with different data. Equation 5 starts with costs for the BOS of $\$ 1.29$ in 2009 and decreases by $16 \%$ per year; the rate of decrease at FS. This is a very rapid decrease which gives BOS costs of $\$ 0.50 / \mathrm{Wp}$ in 2014 , i.e. about the same as the projected manufacturing costs for panels from FS, and stagnates at $\$ 0.24 / \mathrm{Wp}$ after year 2035. If margins for BOS decrease from $30 \%$ to $20 \%$ at the same speed as was given above for margins of PV panels, then the sales price of BOS would decrease from $\$ 1.68$ in 2010 to $\$ 0.70$ in 2015 and $\$ 0.24 / \mathrm{Wp}$ after 2035. Indeed, part of the development anticipated here took place during the review of this paper (see Ahearn et al. 2011, p. 17).

Figure 2 illustrates the projected sales price of PV systems per Wp, which includes panels and BOS (left axis) and the resulting costs of electricity in $\phi / \mathrm{kWh}$

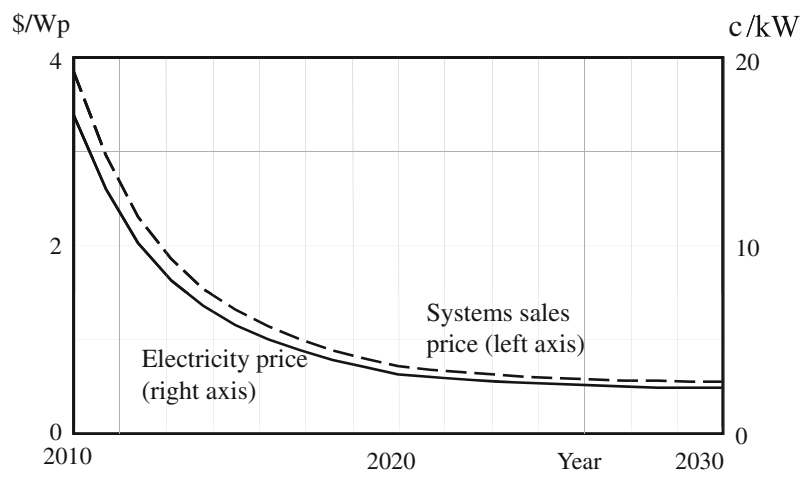

Fig. 2 Sales price of systems (panel and BOS) and resulting price of electricity 
(right axis). Costs decline from $17.5 \varnothing$ in 2010 (shown above) to $2.5 \not$ in 2050 for areas with insolation of $2,300 \mathrm{kWh} / \mathrm{m}^{2} /$ year.

Since this cost estimate uses assumptions with some degree of uncertainty, sensitivity of resulting costs is tested for variations of key parameters as summarized in Table 4. This analysis uses a wide range of variations. Some parameters have remarkable low effects. For example, if energy growth rates up to 2050 vary between $1 \%$ /a up to $2.3 \%$ /a, the number of doublings in manufacturing is between $\sim 12$ and $\sim 13$ and the resulting difference in manufacturing costs is $0.6 \%$.

Figure 3 illustrates the results of the sensitivity analysis (cost estimates for areas with insolation of $2,300 \mathrm{kWh} / \mathrm{m}^{2} /$ year). For all parameter values the generation costs per kWh of electricity will fall below $10 \not$ by 2012 . In the most unfavorable case, grid parity at $6 \phi / \mathrm{kWh}$ is only reached in 2018; however, it will most likely occur before 2018. (The line a50 in Fig. 3, the development without parameter variations, is here the curve of lowest costs.) This analysis is valid for utility-scale installations in regions with high annual insolation of ca $2,300 \mathrm{kWh} / \mathrm{m}^{2}$.

For a broad range of parameter variations costs fall below $5 \phi / \mathrm{kWh}$ after 2020 , and below $2.8 \phi / \mathrm{kWh}$ after 2030. The outcome is neither much affected by considerable differences in global economic growth rates, nor by additional considerable differences in energy efficiency, as most of the doubling in

Table 4 Parameters and their values used for sensitivity analysis

* These values take into account a footing of $\$ 0.20 / \mathrm{Wp}$

Source own calculations and sources given in article main text

\begin{tabular}{llll}
\hline Parameter & $\begin{array}{l}\text { Standard } \\
\text { value }\end{array}$ & $\begin{array}{l}\text { Minimum } \\
\text { value }\end{array}$ & $\begin{array}{l}\text { Maximum } \\
\text { value }\end{array}$ \\
\hline $\begin{array}{l}\text { Cost decrease of panels per } \\
\text { doubling* }\end{array}$ & 0.71 & 0.65 & 0.90 \\
$\begin{array}{l}\text { Footing panel (\$) } \\
\text { Margin panel (\%) }\end{array}$ & 0.2 & 0.1 & 0.3 \\
$\begin{array}{l}\text { Cost decrease BOS in \%/year* } \\
\text { Footing BOS (\$) }\end{array}$ & 13 & 10 & 40 \\
Margin BOS (\%) & 0.2 & 0.1 & 0.3 \\
\hline
\end{tabular}

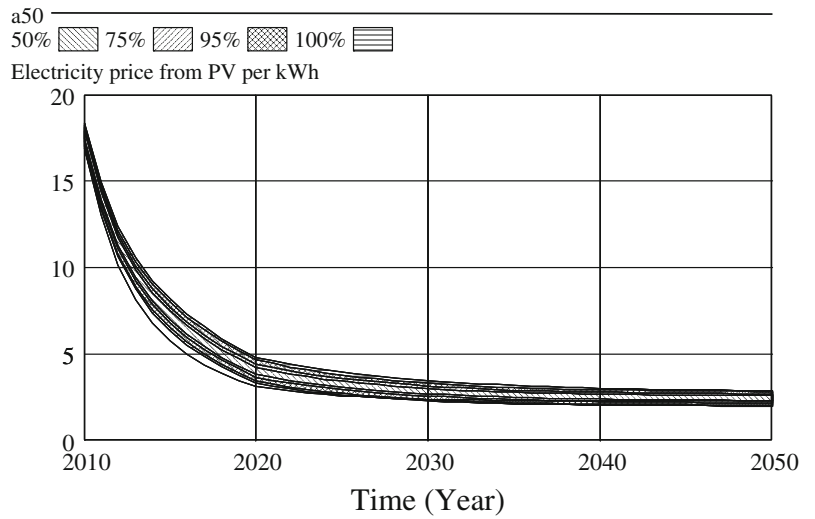

Fig. 3 Sensitivity analysis of electricity price in $\mathrm{c} / \mathrm{kWh}$ of electricity from PV 
manufacturing is necessary anyway to enable solar to contribute markedly to global energy supply. As was said above, the only issue that might prevent the low prices shown in the sensitivity analysis would be persistently high costs of the footings of panels and BOS. High footing in PV panels is unlikely because PV is a semiconductor technology with a very rapid cycle of development. For computer chips this type of technology has for four decades seen ever lower manufacturing costs. Also, there are no known limiting factors that could prevent low costs, such as scarcity of resources (given the abundance of silicon and emerging new thin-film materials) or lack of area. High footing of BOS is even more unlikely, as BOS is a pretty straightforward issue which can be highly automated, uses standard materials and is a good candidate for marked decrease of costs from large-scale manufacturing. This is illustrated by the recent very rapid decrease of costs of BOS from $\$ 2.70 / \mathrm{Wp}$ to below $\$ 1 / \mathrm{Wp}$.

It can be concluded that low costs for photovoltaic energy are highly likely.

\section{Development of investment and employment in the PV sector}

In this section we determine the evolution of investment expenditure and employment based on the learning curves from the preceding section, using data and figures from the roadmaps from FS. The results for FS are to be considered as representative also for the overall market as the price leader, in this case FS, determines the path that the other companies have to take in order to survive in a strongly competitive market. It is most interesting that the financial size of the sector increases with the volume of production, but simultaneously decreases with the volume of production as increasing volume decreases manufacturing costs. The product of Eq. 4 with the manufacturing capacity $C(t)$ (Eq. 1$)$ with initial value $C_{0}$ $(19 \mathrm{GW})$ and $n(t)=\ln \left(C(t) / C_{0}\right) / \ln (2)$ describes this development. Here, $\tau=t-2010$

$$
\tilde{c}_{2}(t) \cdot C(t)=\left(0.05+1.58 \cdot 0.811^{n}\right) \cdot\left(19+28000 \cdot \tau^{2.4} /\left(45^{2.4}+\tau^{2.4}\right)\right)
$$

\subsection{Capital stock and manufacturing of First Solar}

During 2009 FS increased its manufacturing capacity by 500 MW from 720 to 1,220 MW with investments of $\$ 472$ million (FS 2010a), corresponding to investments of $\$ 944$ million/GWp. $10 \mathrm{TWp}$ of manufacturing capacity in 2050 would thus need investments of $\$ 9,480$ billion at the costs of 2010, if all companies are as effective as FS, otherwise the amount would be higher.

Continued learning in this industry decreases the investment in the PV sector which is necessary for this manufacturing capacity. For example, learning curve (4) $\tilde{c}_{2}(t)=0.05+1.58 \cdot 0.811^{n}$ with $n=10$ doublings gives panel costs of $\$ 0.21 / \mathrm{Wp}$ in year 2050 instead of the panel manufacturing costs of $\$ 0.75 / \mathrm{Wp}$ at the end of 2010. Accordingly, the resulting market capitalization would be in the range of $\$ 9480$ billion $\times 0.21 / 0.75=\$ 2,650$ billion, globally. Both investment and employment must be even lower than that number, as a footing in the panel 
manufacturing costs implies that the same fraction of the $\$ 0.21 / \mathrm{Wp}$ are needed for materials, energy etc., not for manufacturing capacity and employment. We will now provide a range of possible outcomes for investment and employment in the solar sector.

\subsection{Employment and investment}

At the end of 2009, FS globally engaged 4,500 employees (USSCEP 2010) to develop, manage, make acquisitions and run the manufacturing capacity of 1,220 MW. Hence for a capacity of $1 \mathrm{GW} / \mathrm{y}, 3,690$ employees is the most current labor demand.

Work force is additionally needed for the installation of PV panels. Currently, the installation of panels is not as automated as their production (e.g. RMI 2010). For the residential construction sector a fully automated installation seems difficult also in the future; however, at the utility scale, achievement of a high degree of automation is likely. As experts assume the same footing for manufacturing costs of panels and costs for their BOS (as described above), the costs for both would again become quite similar at the larger scale of the utility level.

How will significant technological progress change the relative relevance of the factor inputs of labor and capital? In empirical macroeconomic studies most technological progress is found to be Hicks neutral, i.e. leaving the marginal rate of substitution between input factors unaffected. More generally, most technological change is found not to change the relative demand of capital and labor in production (the total factor productivity, the context is the so called "Solow residual", e.g. Hall 1988). Without contrary information for the PV sector, the labor-capital input ratio is assumed to be constant over time, while technological progress raises the productivity of both factors.

For an analytical description of this relationship we normalize Eq. 7 to the value of 1 in 2009 and multiply the normalized function with the initial values of employees and capital investment expenditures needed to produce $1 \mathrm{GWp} /$ year of photovoltaic panels. The resulting functions give time series for the specific labor demand $M_{1}(t)$ and capital investment $K_{1}(t)$

$$
\begin{aligned}
& M_{1}(t)=c_{i}^{-1} c(t) M_{0} \\
& K_{1}(t)=c_{i}^{-1} c(t) K_{0},
\end{aligned}
$$

where $c(t)$ is given by Eq. $7 ; c_{i}$ normalizes $c(2009) c_{i}^{-1}$ to the value of $1 ; M_{0}$ represents the employees needed and $K_{0}$ the capital investment needed to produce $1 \mathrm{GW}$ of panels in 2009. Figure 4 illustrates the development over time of the specific labor demand.

\subsection{Manufacturing capacity and investment}

The analogue procedure gives the specific amount of invested capital over time for $1 \mathrm{GWp} /$ year of manufacturing capacity, Fig. 5. The initial value is $\$ 944$ million/ GWp in 2009 as calculated above. 


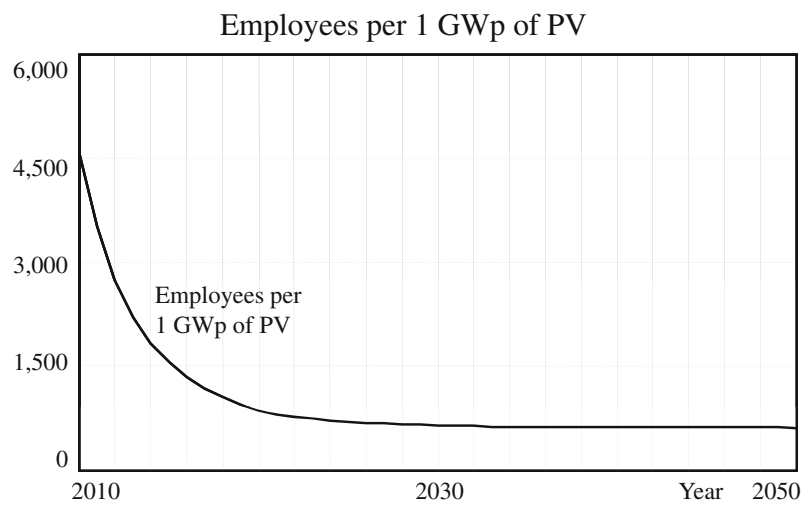

Fig. 4 Specific employment per $1 \mathrm{GWp}$ /year manufacturing capacity over time

The numbers on manufacturing capacity given in Table 3 together with the specific numbers for employment and investment per GWp as shown in Figs. 4 and 5 , allow an estimate of the development of employment and investment.

\subsection{Global invested capital and employment in the solar sector}

The development of the globally invested capital is calculated as the product of the global manufacturing capacity, one example is Table 3, which we use here, times the costs per unit of manufacturing capacity (Fig. 5). The resulting Fig. 6 shows a transition at around 2035 when global manufacturing capacity is approaching demand and its growth curve levels off.

The invested capital shown in Fig. 6 is lower than could be expected given present investment costs due to decreasing costs for PV manufacturing capacity resulting from economies of scale and global competition. As was stated before, total systems cost could decrease from their present value of about $\$ 2 / \mathrm{Wp}-\$ 0.40 / \mathrm{Wp}$, i.e. by a factor of 5 , and thus specific investment has to decrease by at least this factor.

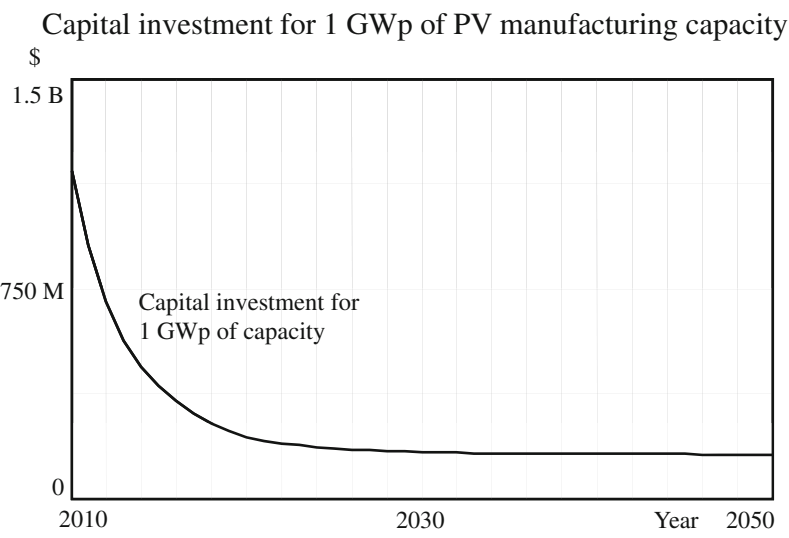

Fig. 5 Development of specific investment for $1 \mathrm{GWp} /$ year of manufacturing capacity 


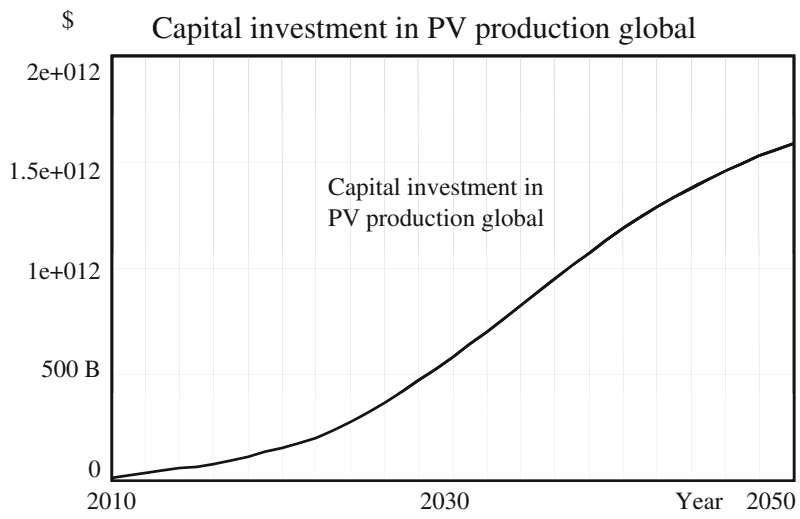

Fig. 6 Projected global capital investment values in photovoltaic manufacturing capacity

In addition to capital investment shown in Fig. 6, investment is needed for manufacturing capacity and BOS as well as for extended transmission capacity. If the costs of panel manufacturing and BOS are similar, this would about double the amount of investment; if transmission costs are at $1 / 3$ of electricity costs, this would further increase investment by about $1 / 3$.

Similarly, the estimate of global development of employees needed in the PV production sector, Fig. 7 , is derived as the product of the growth rate of global manufacturing capacity times the specific employment needed per unit of manufacturing capacity (Fig. 4). As in the case of investment, the number of jobs is surprisingly low in comparison to what might initially be expected, and for the reasons given above.

\subsection{Sensitivity analysis of capital investment and employment}

Whereas electricity costs do not change much if parameter values are changed according to Table 4, the development of capital investment is quite sensitive to changes of these parameter values, as is given in Fig. 8. The lower range of investment is due to both, low total systems prices for solar energy and low increase in energy demand. The outcomes could be different by a factor of 2 . However, these extremes are highly unlikely as we might expect either high prices for solar energy and, accordingly, low energy demand, or low prices for solar and high energy demand. Hence, the middle of the range of this sensitivity analysis shows the more likely outcomes.

Due to the tight connection between investment and employment, the uncertainty in outcomes of employment is very similar to those in the subject of capital investments.

\subsection{Further development of manufacturing capacity}

The present rush towards grid parity will not trigger an immediate boom for the PV industry. The energy sector is a very mature sector with long time horizons. Mature sectors are slow in adopting radical change. For example, $\sim 4 \mathrm{TW}$ of electricity 


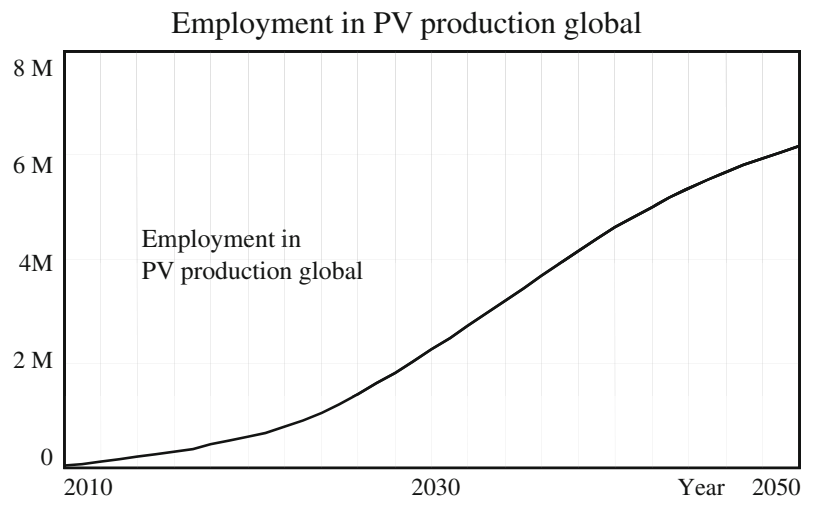

Fig. 7 Global employment in photovoltaic manufacturing

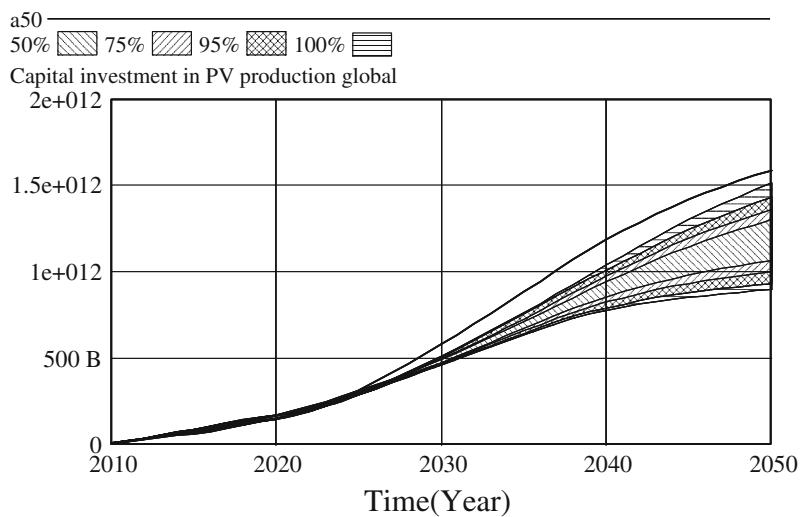

Fig. 8 Sensitivity of investment to changes of crucial parameters

would be needed to meet $80 \%$ of the total energy demand of the US in 2050 (Fthenakis et al. 2009). The transmission lines with the highest capacity are the High-Voltage DC (HVDC) transmission lines in China with a length of about $3,000 \mathrm{~km}$ and a capacity of $6 \mathrm{GW}$ at a cost of $\$ 2.35$ billion (ABB 2010). The transmission of $\sim 4 \mathrm{TW}$ from the US Southwest with an average line length of 2,000 km would need 670 lines with $6 \mathrm{GW}$, each with present total investment costs of about $\$ 1$ billion. Fthenakis et al. (2009) present reasons for the considerable decrease of costs, as HVDC is a new generation of transmission technology. Such huge investments in transmission lines in addition to high investments in new generation capacity are one reason why decision-making in the energy sector has to be considerate and is often slow.

This might change once installations of solar power stations and HVDC lines are sufficiently proven. Then, many investors will want to put money into solar generating capacity, storage and transmission lines. Breakthroughs with a high potential - here the achievement of grid parity by PV and its practicability — often cause a buildup of large overcapacity; as described in the famous "Hype Cycle" 
from Gartner (2010). Companies basically want to expand as fast as possible so that they, and not their competitors, can benefit from economies of scale, as this is imperative for their survival. Thus, overcapacity is a common phenomenon to be expected at some point in time. A second economic issue that facilitates an extension of the PV sector is the growth in energy demand. New capacity, whether based on fossil fuels or renewables, has to be built from scratch anyway; and once solar is competitive, the new capacity could be solar in most cases. Additionally, all types of power plants have a limited lifetime, e.g. 30-40+ years for coal power plants. If the levelized cost of electricity (LCOE) from PV becomes lower than LCOE of other energies, then an increasing share of capital expenditures will be put into PV, for both new capacity and replacement of existing capacity, as this would be the best option with respect to return on investment. 2010 already saw an unexpectedly high growth of investment in renewable energy, in both, developing and developed countries (UNEP 2011).

\section{Conclusions}

The field of renewable energy, and here in particular photovoltaics, experiences an intriguing development and expansion. This is due to the very rapid decrease of costs of renewable energy as well as to manifold problems in the established energy sector. PV has now become competitive in some regions and is projected to become competitive soon between $35^{\circ}$ South and $35^{\circ}$ North, where $2 / 3$ of humanity live. As PV is a semiconductor technology, applied to the field of energy, the immediate promise is that it might become as transforming as the information and communication technology. Interestingly, the technology in the field of PV is now enabling the implementation of a new energy system, almost completely based on renewable energy. The energy sector currently accounts for about $8 \%$ of global GDP, which points out the economic relevance of a transition of this sector.

This article addressed the quantitative scope for expansion of solar electricity to answer questions such as: How fast can solar electricity supply be built up? What investment levels are necessary for a dominant share of global energy supply? Which size of labor force will be needed?

We started by showing that-with current knowledge-about $90 \%$ of total energy demand can be covered by energy supplied in the form of electricity, and thus can be generated from solar electricity. This includes shifting road transport to electric vehicles, for example. Using standard global economic (3.3\%/year) and energy efficiency (1\%/year) growth rates and acknowledging the shift to electricity we derive a main scenario for total global electricity demand in 2050 at 16.5 TW, with a range derived from the IPCC SRES scenarios at 8-26 TW. Applying solar insolation this is translated to a solar capacity of 66 TWp in 2050, and one specific scenario for building such a capacity is developed. This scenario is shown to be both quite realistic and is based on lower capacity growth rates than those used in standard literature.

The subsequent two main steps in this article are (1) the derivation and analysis of the details of learning curves for PV module (panel) and system (balance of 
system, BOS) production to derive the development of production costs for both over time, governed by number of output doublings, and (2) the translation of these costs and related labor force demands to global demand figures, using the development path of global capacity as derived above.

We find that the projected sales price of PV systems per Wp, which includes panels and BOS, results in costs of electricity declining from $17.5 \phi / \mathrm{kWh}$ in 2010 to $2.5 \phi$ in 2050 (for areas with solar insolation of $2,300 \mathrm{kWh} / \mathrm{m}^{2} /$ year).

Sensitivity analysis of these results, using a large range of values for the underlying parameters, shows that some parameters have remarkable low effects. For example, if energy growth rates up to 2050 vary between $1 \%$ /a up to $2.3 \%$ /a, the number of doublings in manufacturing is between $\sim 12$ and $\sim 13$ and the resulting difference in manufacturing costs is only $0.6 \%$ in 2050 .

For all parameter values the generation costs per $\mathrm{kWh}$ of electricity will fall below $10 \phi$ by 2012 . In the most unfavorable case, grid parity at $6 \phi / \mathrm{kWh}$ is only reached in 2018; however, it will most likely occur before 2018 (with all values given here valid for utility-scale installations in regions with high annual insolation of about $2,300 \mathrm{kWh} / \mathrm{m}^{2}$ ).

Concluding on overall investment requirements for building up the PV capacity to cover $90 \%$ of total global energy demand by 2050 we find the bi-directed impact of growing output. Directly it increases financial demands, but indirectly-by economies of scale and other learning effects-it reduces unit costs. As a net effect we derive a projected global capital investment value in photovoltaic manufacturing capacity at 500 billion US\$2010 by around 2030 and 1,500 billion by 2050 . Sensitivity analysis shows that this figure may be only at half of its value in 2050, albeit only at the unlikely combination of lowest capacity expansion and nevertheless highest learning advantages.

In addition to this capital investment, investment is needed for manufacturing capacity and BOS as well as for extended transmission capacity. If the costs of panel manufacturing and BOS are similar, this would about double the amount of investment; if transmission costs are at one-third of electricity costs, this would further increase investment by about one-third.

In terms of labor demand, employment in the production of panels is projected to be at 2 million in 2030 and at 6 million in 2050 for our main scenario ( 6 million is a share of $0.2 \%$ of the current global labor force of 3.2 billion). Sensitivity of these numbers is the same as with capital investment.

While the 2012 IPCC Special Report on renewable energy resources (IPCC, 2012) gives a very thorough overview of direct solar technologies and their technical potential (as referenced above), it limits itself to cover projections up to 2020 only for this very dynamic field. The present article gives a specifically reasoned scenario and sensitivity analysis for PV development up to 2050, complementing IPCC (2012) in this respect.

The field of solar electricity sees an interplay between competing technologies, companies, and countries. For future research there is a unique opportunity to use economic theories and experience to observe and assess this young field, to arrive at conclusions, to monitor the actual development on the basis of earlier conclusions and to use all insights for doing a good job in providing timely advice in a field that 
is very likely to substantially grow, will absorb large sums for investment and offers manifold opportunities in employment.

Acknowledgments This publication arose from the research project Energ.Clim funded by the Austrian Climate and Energy Fund and carried out within its program line "New Energy 2020". The fourth author was supported by the Climate Decision Making Center created through a cooperative agreement between the National Science Foundation (SES-0345798) and Carnegie Mellon University.

\section{References}

ABB (2010) Ultra high voltage DC systems. ABB Power Technologies AB. http://www.abb.com/hvdc. Accessed 8 Sept 2010

Ahearn M, Widmar M, Brady D (2011) First solar 2012 guidance. http://www.FirstSolar.com, investor relations

Ayres U (2008) Sustainability economics: where do we stand? Ecol Econ 67(2):281-310

Biello D (2009) How to use solar energy at night. Scientific American, 18 Feb 2009

Bloomberg (2010) US solar poised for \$100bn growth surge. http://www.bloomberg.com/news/2010-1025/us-solar-poised-for-100bn-growth-surge.html. Accessed 25 Oct 2010

Breyer C, Gerlach A, Mueller J, Behacker H, Milner A (2009) Grid-parity analysis for EU and US regions. In: Proceedings of the 24th European Photovoltaic Solar Energy Conference 2009, pp $4492-4500$

Buller B (2008) Thin film technology: the pathway to grid parity. http://2008.thinfilmconference.org/ fileadmin/TFC_docs/videos/081114_TFC_02_002_Buller.pdf. Accessed 07 Sept 2010

Cheyney T (2010) Run-rate reality: First Solar's close-to-the-vest capacity projections don't add up. PVTech. http://pv-tech.org/chip_shots_blog/run-rate_reality_first_solars_close-to-the-vest_capacity_ projections_dont_a. Accessed 28 Oct 2010

Desertec Foundation (2010) Clean power from deserts. Protext, 34 pp

DLR (2006) Trans-mediterranean interconnection for concentrating solar power. Final report. German Aerospace Center, Germany. http://www.dlr.de/tt/trans-csp. Accessed 2 Dec 2010

EC (European Commission) (2009) Milestones in ESTI's development 1977-2009. European Commission Joint Research Centre, European Solar Test Installation

EC (European Commission) (2011) Manage energy. Buildings. http://www.managenergy.net/buildings_ links.html. Accessed 12 Oct 2010

EIA (U.S. Energy Information Administration) (2011) International Energy Outlook 2011

EU (European Union) (2010) Directive 2010/31/EU of the European Parliament and of the Council of 19 May 2010 on the energy performance of buildings. http://eur-lex.europa.eu/JOHtml.do?uri=OJ:L: 2010:153:SOM:EN:HTML

EU (European Union) (2011a). Energy savings measures for buildings. http://www.managenergy.net/ buildings_links.html. Accessed 8 Dec 2011

EU (European Union) (2011b) A roadmap for moving to a competitive low carbon economy in 2050. http://eur-lex.europa.eu/LexUriServ/LexUriServ.do?uri=COM:2011:0112:FIN:EN:PDF. Accessed 10 Dec 2011

FS (First Solar) (2010a) Fundamentals—annual balance sheet. http://investor.firstsolar.com/phoenix. zhtml?c=201491\&p=irol-fundBalanceA. Accessed 31 Aug 2010

FS (First Solar) (2010b) First Solar investor relation 10-K and 10-Q. http://investor.firstsolar.com/ phoenix.zhtml?c=201491\&p=irol-irhome. Accessed 5 May 2011

Fthenakis V, Mason JE, Zweibel K (2009) The technical, geographical, and economic feasibility for solar energy to supply the energy needs of the US. Energy Policy 37:387-399

Gartner (2010) Research methodologies: gartner hype cycle. http://www.gartner.com/technology/ research/methodologies/hype-cycle.jsp. Accessed 6 May 2010

Goldstein J, Yakupov I, Breen B (2010) Development of large area photovoltaic dye cells at 3GSolar. Sol Energy Mater Sol Cells 94:638-641

Green MA (2010) Learning experience for thin-film solar modules: First Solar, Inc. case study. Prog Photovolt Res Appl 19:498-500

Grossmann WD, Grossmann I, Steininger KW (2010) Indicators to determine winning renewable energy strategies with an application to photovoltaics. Environ Sci Technol 44(13):4849-4855 
Grossmann WD, Grossmann I, Steininger KW (2011) Solar electricity generation across large geographic areas, part I: a method to optimize site selection, load distribution and storage. Manuscript under review

Hall R (1988) The relation between price and marginal cost in U.S. industry. J Polit Econ 96:921-947

IEA (International Energy Agency) (2009) Key world energy statistics. International Energy Agency, Paris and OECD, Paris, France

IEA (International Energy Agency) (2010) Key world energy statistics. International Energy Agency, Paris and OECD, Paris, France

IER (Institute for Energy Research) (2010) A primer on energy and the economy: energy's large share of the economy requires caution in determining policies that affect it. http://www. instituteforenergyresearch.org/2010/02/16/a-primer-on-energy-and-the-economy-energys-large-shareof-the-economy-requires-caution-in-determining-policies-that-affect-it/. Accessed 10 Dec 2011

IPCC (2012) Renewable energy sources and climate change mitigation, special report of the intergovernmental panel on climate change. Cambridge University Press, Cambridge

Kamat PV, Schatz GC (2009) Nanotechnology for next generation solar cells. J Phys Chem 113(35):1-3

Korosec K (2011) 3 companies that are leading the U.S. solar boom. Smartplanet, 12 Sept 2011

Lewis NS (2007a) Powering the planet. Eng Sci 2:12-23

Lewis NS (2007b) Powering the planet. Powerpoint presentation. http://www.caer.uky.edu/ podcast/Lewis-KESummitOct2007r.pdf. Accessed 11 Dec 2011

Maddison A (2001) The world economy: a millennial perspective. OECD, Paris

Mahon S (2011) Switching tactics: solar trust of America selects PV over CSP for first phase of $1 \mathrm{GW}$ Blythe park. PVTech. http://www.pv-tech.org/news/switching_tactics_solar_trust_of_america_ selects_pv_over_csp_for_first_phas. Accessed 18 Aug 2011

Metha S (2011) Annual data collection results: 2010. PV News, vol 30. http://www. greentechmedia.com/articles/print/pv-news-annual-data-collection-results-cell-and-module-productionexplode-p. Accessed 9 May 2011

MIT (2010). The future of natural gas: an interdisciplinary MIT study. http://web.mit.edu/mitei/ research/studies/naturalgas.html. Accessed 8 Aug 2011

Nakicenovic N, Davidson O, Davis G, Grübler A, Kram T, Lebre La Rovere E, Metz B, Morita T, Pepper W, Pitcher H, Sankovski A, Shukla P, Swart R, Watson R, Dadi Z (2001) Summary for policymakers. Special Report on Emission Scenarios of WG III of IPCC

Palmintier B, Hansen L, Levine J (2008) Spatial and temporal interactions of solar and wind resources in the next generation utility. In: SOLAR 2008 Conference and Exhibition. San Diego, CA, 3-8 May 2008

Patzek TW, Croft GD (2010) A global coal production forecast with multi-Hubbert cycle analysis. Energy 35(2010):3109-3122

PB Power and Royal Academy of Engineering (2004) The costs of generating electricity. The Royal Academy of Engineering, PB Westminster, London. ISBN 1-903496-11-X

Pew Charitable Trusts (2011) Who's winning the clean energy race. Pew Charitable Trusts, Philadelphia, PA

Raugei M, Frankl P (2009) Life cycle impacts and costs of photovoltaic systems: current state of the art and future outlooks. Energy 34:392-399

REN 21 (2010) Renewables 2010 global status report. REN 21 Secretariat, Paris, France, 2010. http://www.ren21.net/Portals/97/documents/GSR/ REN21_GSR_2010_full_revised\%20Sept2010.pdf. Accessed 25 Sept 2010

REN 21 (2011) Renewables 2011 global status report. REN 21 Secretariat, Paris, France, 2011. http://bit.ly/REN21_GSR2011. Accessed 25 Sept 2010

RMI (2010) Solar PV balance of system. Rocky Mountain Institute. http://www.rmi.org/rmi/SolarPVBOS . Accessed 21 Jan 2011

Trancik JE, Zweibel K (2006) Technology choice and the cost reduction potential of photovoltaics. http://www.nrel.gov/pv/thin_film/docs/tranciklearningcurve_wcpec2006.pdf. Accessed 24 Aug 2010

UNEP (United Nations Environment Programme) and Bloomberg New Energy Finance (2011) Global trends in renewable energy investment 2011. ISBN: 978-92-807-3183-5

Unold T, Schock HW (2011) Nonconventional (non-silicon-based) photovoltaic materials. Annu Rev Mater Res 41(15):1-25 
USSCEP (U.S. Senate Committee on Environment \& Public Works) (2010) Joint hearing: solar energy technology and clean energy jobs, Tempe, AZ, 28 Jan 2010. http://www.firstsolar.com/en/ news/news_SenateCommitteeEPW012009.php. Accessed 31 Aug 2010

Wadia C, Alivisatos AP, Kammen DM (2009) Material availability expands the opportunity for largescale photovoltaics deployment. Environ Sci Technol 43:2072-2077

Wang X, Liu D, Li J (2010) Organic photovoltaic materials and thin-film solar cells. Front Chem China $5(1): 45-60$

Zaman A, Lockman S (2011) Solar industry growth. Piper Jaffray Investment Research, Minneapolis

Zweibel K (2005) Thin films and the system-driven approach. NREL/CP-520-36968, 2004 DOE Solar Energy Technologies Program Review Meeting, Denver, Colorado, 25-28 Oct

Zweibel K (2006) The terawatt challenge for thin film photovoltaics. In: Poortman J, Arkhipov V (eds) Thin film solar cells. Wiley, London

Zweibel K, James M, Fthenakis V (2008) Solar grand plan. Sci Am 298(1):64-73 